\title{
Measurements of short-term turnover of epifauna within seagrass beds using an in situ staining method
}

\author{
Robert K. Howard* \\ Harbor Branch Institution, R. R. 1, Box 196A, Fort Pierce, Florida 33450, USA
}

\begin{abstract}
An in situ staining technique was developed to measure mobility levels of epifauna within a heavily vegetated habitat. Mobile epifauna of a seagrass (Halodule wrightii) bed in the Indian River lagoon, Florida (USA), were stained by temporary confinement of a neutral red solution to $0.56 \mathrm{~m}^{2}$ areas of substrate. Subsequent replacement of stained by unstained fauna within treated areas provided a measure of the rate of turnover of individuals. Retention of stain by treated animals was reliable for major crustacean and gastropod taxa over periods of at least $12 \mathrm{~h}$, and stain treatment did not affect long-term survivorship of aquarium-held epifauna. Field experiments indicated that seagrass-associated crustacean taxa can be highly mobile $>50 \%$ turnover of individuals of a caridean shrimp species occurred in $3 \mathrm{~h}$. Gastropods were less mobile, though some species approached $50 \%$ turnover in $6 \mathrm{~h}$. Small-scale patterns of distribution of epifauna may change considerably in a matter of hours.
\end{abstract}

\section{INTRODUCTION}

Recent work has demonstrated that macrofauna and meiofauna can be highly mobile. Many benthic species undertake regular nocturnal excursions into the water column (Williams \& Bynum 1972, Robertson \& Howard 1978, Hobson \& Chess 1979, Alldredge \& King 1980, in press, Dauer et. al. 1980; Ohlhorst 1982) and defaunated sites often are heavily colonized within a few hours (Sherman \& Coull 1980, Thistle 1980, Bell \& Devlin 1983, Alldredge \& King in press, Virnstein \& Curran, unpubl.). If such behaviour is widespread among benthic taxa, it should be expected that small-scale distributions of organisms are extremely dynamic, and perhaps are completely reorganized on a daily basis.

Despite evidence for high mobility of many benthic faunas, quantitative documentation of mobility of benthic organisms in the field is scant. Unresolved questions include: How far do animals move? Is a majority of individuals in a population mobile, or are just a few responsible for observed demersal behaviour

- Present address: CSIRO Division of Fisheries Research, PO Box 20, North Beach, WA 6020, Australia and recolonization? How long do individuals remain in one area? Is mobility only significant at night and/or in certain seasons?

Clearly, the movements of large numbers of individuals in any one habitat need to be monitored in order to address these questions. This may present little difficulty for relatively conspicuous and slow moving organisms in some habitats, e.g. gastropods of rocky habitats. However, structurally more complex habitats, such as seagrass beds, and/or the prominence of small organisms capable of rapid movement, present more severe methodological problems. Organisms cannot be tracked visually and most mark-recapture methods are not applicable because the small size and usually high densities of many species preclude individual marking. Colonization experiments may provide useful information about short-term rates of movement into unoccupied habitat (Alldredge \& King 1980, in press, Bell \& Devlin 1983) and can be used to measure distances over which fauna can disperse in the short term (Gunnill 1982, Virnstein \& Curran unpubl.). They do not, however, provide information about the movement of organisms in established natural habitats or the turnover of individuals at a given site. Rapid colonization of new or disturbed sites 
is not necessarily an indication of high levels of mobility within a population; a few very mobile individuals could alone maintain rapid colonization levels. Additionally, if behavioural interactions are important, rates of movement into vacant habitat may differ from movement into established habitat.

The present paper describes a technique of in situ marking of epifauna which holds certain advantages over alternative methods of assessing population mobility. In this method a non-toxic biological stain is temporarily confined to water overlying an area of substrate. Organisms present absorb stain from solution while those outside the treated area remain unstained. After the containing structure is removed the area is left undisturbed for a predetermined period of time during which stained and unstained epifauna may migrate between treated and untreated areas. Subsequent sampling of the treated area and determination of the ratio of unstained/stained individuals provides a measure of this exchange and thus of the temporal stability of distributions. Handling of individuals is avoided prior to final collection and disturbance to the habitat is minimal.

A variation on this technique has been used previously by Nixon (1976) in a study of the microdistribution of sandy beach gastrotrichs. However, the method used to apply stain necessarily resulted in severe physical disturbance of the substratum and hence was thought likely to produce serious behavioural artifacts in the subject animals.

Here the in situ staining method is applied to mobile epifauna of a seagrass bed and the reliability of the technique is tested under field conditions.

\section{MATERIALS AND METHODS}

Field work was carried out in the Indian River lagoon, Florida, in shallow beds of the seagrass Halodule wrightii Aschers. The study site was located immediately north of Link Port $\left(27^{\circ} 32.2^{\prime} \mathrm{N}, 80^{\circ} 20.9^{\prime}\right.$ W), approximately $50 \mathrm{~m}$ from shore (see Gore et al. 1981 for a detailed description). During the study, water depth was always $<1 \mathrm{~m}$ and varied from 0.15 to $0.60 \mathrm{~m}$ at low tide. Water temperature was 11 to $32^{\circ} \mathrm{C}$ and salinity was 29 to $36 \%$. Sediments are $>90 \%$ quartz sand (Hoskin 1983) and are low in organics. Water used in aquarium experiments was pumped from the Indian River lagoon.

Staining procedure and field experiments. Staining of epifauna in situ was achieved by the introduction of a solution of neutral red to an enclosed area of substratum and overlying water at low tide. Neutral red was selected as a vital stain because it is non-toxic, was found to be readily absorbed by epifauna, and was more conspicuous than other useful stains, e.g. bismark brown or methyl green (see Smith \& Present 1983 for a summary of published records on the use of immersion stains).

Boxes, $60 \mathrm{~cm}$ tall and open-ended, were used to confine stain to $0.75 \times 0.75 \mathrm{~m}\left(=0.56 \mathrm{~m}^{2}\right)$ areas of the shallow seagrass bed. Boxes were constructed from $5 \mathrm{~mm}$ thick PVC sheets, and were slightly flared towards the top allowing them to be stacked together for storage and transportation. Top edges were reinforced by angle strips of PVC.

Approximately $1 \mathrm{~h}$ before low tide, 4 boxes were positioned at haphazardly selected sites within a $20 \times 20 \mathrm{~m}$ area in an extensive Halodule wrightii bed. Care was taken to ensure that the lower edges of the boxes formed a seal with the sediment and that water depth was well below the top of the boxes. Neutral red, in concentrated solution, was then added in an amount calculated to give a final concentration of 8 to $10 \mathrm{mg}$ $\mathrm{l}^{-1}$, and briefly stirred. The positions of the corners of boxes on the sediment were marked to allow accurate repositioning of boxes for later collection of epifauna.

One $\mathrm{h}$ after the addition of stain, boxes were removed and the stain allowed to disperse. Dispersal was rapid and stain could not be visually detected in the water after about 2 to $3 \mathrm{~min}$.

Following in situ staining, the area was left undisturbed for 3 or $6 \mathrm{~h}$ after which boxes were relocated at their previous positions. Three hour experiments were run on 3 January 1983 (during daylight); $6 \mathrm{~h}$ experiments were run on 6 October 1982 (day) and 7 October 1982 (night). Following the relocation of boxes, the seagrass canopy inside boxes was dip-netted thoroughly with a $1 \mathrm{~mm}$ mesh net. Epifauna collected from each box was placed in a large plastic bag with seawater and kept cool for return to the laboratory.

Samples were processed in the laboratory within $5 \mathrm{~h}$ of collection. Plant material was briefly rinsed in freshwater to remove animals. Finer plant material and crustaceans were then separated from gastropods by elutriation with seawater. Gastropods were preserved in $5 \%$ formalin for later examination and crustaceans were examined immediately. As internal staining was used to identify stain-treated crustaceans (Table 1), it was necessary to examine most members of this group while still alive (and their tissues strongly transparent). Stain-treated gastropods were identified by inspection of external tissues (Table 1) and hence later identification was not hampered by preservation in $5 \%$ formalin.

Epifauna were sorted into species and individually examined under a dissecting microscope. Each individual was scored as stained or unstained according to criteria determined in stain retention tests (see section below and Table 1). To facilitate the examination of 
external soft tissues of gastropods, the shells of preserved specimens first were dissolved with hydrochloric acid.

Reliability of stain as a marker. Two major potential sources of error in the application of in situ staining were envisaged: (1) Loss of stain from treated organisms during the experimental period; (2) uptake of stain residual on vegetation, sediments or water in the treated area by immigrating (non-treated) organisms. Field experiments were undertaken to test for occurrence of these artifacts.

After the usual in situ staining treatment, dip-netted epifauna and 2 samples of approximately $30 \mathrm{~g}$ (wet weight) of seagrass were collected from each of 4 boxes. Stain-treated epifauna and 1 seagrass sample from the same box were combined and placed in a 51 plastic container. Sides and lid of containers were constructed from $500 \mu \mathrm{m}$ mesh nylon to allow water exchange. The root-mat of the seagrass was weighted to the bottom of the container with stones so that leaves floated in an upright position. In identical containers, unstained epifauna collected from outside boxes were placed with the second sample of stain-treated seagrass. One of the containers with (a) stain-treated epifauna and stain-treated seagrass and one with (b) unstained epifauna and stain-treated seagrass were placed in each previously stained patch of the seagrass bed; (a) was designed to test for the efficiency of stain retention and (b) tested for uptake by unstained (nontarget) epifauna of residual stain from treated substrate. Trials were run for 3,6 and $12 \mathrm{~h}$. In the latter experiment, seagrass was first rinsed briefly in freshwater to remove any stain-treated animals; prior tests indicated that $>99 \%$ of these animals were removed.

Effect of staining on survivorship. Laboratory experiments in June 1983 compared survivorship of staintreated epifauna with that of unstained epifauna.

The 2 numerically dominant species within the crustaceans and molluscs were utilized in experiments. The shrimps Hippolyte pleuracanthus and Palaemonetes intermedius, and the gastropods Bittium varium and Astyris lunata were collected from the field and held in a flow-through aquarium system in the laboratory for $5 \mathrm{~d}$ prior to the commencement of experiments. Small amounts of chopped pelecypods were provided as food. Following acclimation, 8 replicates of 20 adults each of $H$. pleuracanthus, $B$. varium and $A$. lunata and 20 immature $P$. intermedius were transferred to each of eight $5 \mathrm{l}$ plastic containers with $500 \mu \mathrm{m}$ mesh sides and lids. Immature $P$. intermedius were used to avoid the possibility of predation by large $P$. intermedius on the smaller $H$. pleuracanthus. Four containers were placed under water in each of 2 large plexiglas trays on a water table. Aeration and an inflow of fresh seawater were maintained in each tray.
Stones were added to each container to provide cover and to prevent the containers frorn floating.

At the commencement of the staining treatment, seawater inflows were closed and neutral red was added to 1 tray until a solution of $9 \mathrm{mg} \mathrm{l}^{-1}$ was obtained. One hour later, the inflows were reopened and stain was flushed from the stain-treated tray. When the water had completely cleared of stain, 2 containers from each tray were selected at random and moved to the opposite tray so that 2 stain-treated and 2 control replicates were set in each tray.

Trays were kept under a natural light regime and food added to containers every second day. Daily measurements of water temperature in trays ranged between 27.8 and $29.6{ }^{\circ} \mathrm{C}$. Numbers of surviving individuals of each species were counted 1, 3, and $7 \mathrm{~d}$ after the stain treatment and any dead animals were removed.

\section{RESULTS}

Individuals of most epifaunal taxa were stained conspicuously after $60 \mathrm{~min}$ immersion in 8 to $10 \mathrm{mg} \mathrm{l}^{-1}$ neutral red in seawater (Table 1). Amphipods and caridean shrimps were the most effectively stained crustacean groups. Peracarid species accumulated stain most noticeably in the paired hepatopancreatic caeca located either side of the midgut (Table 1). The isopod Cymodoce faxoni was resistant to staining, while results for decapods were variable. The shrimp Hippolyte pleuracanthus stained most easily. Few hermit crabs, Pagurus maclaughlinae, could be stained. A major proportion of the pink shrimp Penaeus duorarum usually remained unstained, possibly due to burrowing behaviour of some individuals.

Gastropods generally were stained on exposed soft tissues, most prominently in the anterior (dorsal) region (Table 1). An exception was Modulus modulus which has pigmented anterior tissues that mask uptake of stain. Staining of attached epibiota on shells was found to be a useful alternative indicator in this species. Gills of most gastropods were stained (Table 1). Although there was individual variability in the degree of staining, few gastropods were not strongly stained. Any faintly stained individuals were designated as 'unstained' in the ensuing experiments, as non-stain-treated gastropods were occasionally found to develop very light staining in the tests for uptake of residual stain. Although strongly stained food material also was regularly found in the guts of these 'control' gastropods, stain remained confined to the digestive tract.

Staining retention efficiencies of close to $100 \%$ were found in 3, 6 and $12 \mathrm{~h}$ tests (Fig. 1) and errors resulting from the uptake of residual stain by unstained 
Table 1. Efficiency of uptake of neutral red stain from solution by epibenthic species of Indian River seagrass beds, and the locations of conspicuous sites of stain accumulation on individuals. $\mathrm{H}=$ high uptake efficiency $(>90 \%$ of all individuals marked after immersion for $1 \mathrm{~h}$ ) : I = Intermediate (50 to $90 \%$ marked); $\mathrm{L}=$ low (<50\% marked)

\begin{tabular}{|c|c|c|c|c|c|}
\hline \multicolumn{2}{|c|}{ Group } & Species & $\begin{array}{c}\text { Stain } \\
\text { uptake } \\
\text { efficiency }\end{array}$ & \multicolumn{2}{|c|}{ Stain location } \\
\hline \multirow[t]{10}{*}{ CRUSTACEA } & Amphipoda & Cymadusa compta & $\mathrm{H}$ & Hepatopancreas & Surface integument, setae \\
\hline & & Grandidierella bonnieroides & $\mathrm{H}$ & Hepatopancreas & \\
\hline & & Melita appendiculata & $\mathrm{H}$ & Hepatopancreas & \\
\hline & & Corophium spp. & $\mathrm{H}$ & Hepatopancreas & \\
\hline & Isopoda & Erichsonella attenuata & $\mathrm{H}$ & Hepatopancreas & \\
\hline & & Cymodoce faxoni & $L$ & Hepatopancreas & \\
\hline & Decapoda & Hippolyte pleuracanthus & $\mathrm{H}$ & $\begin{array}{l}\text { General, concentrated } \\
\text { in cephalothorax }\end{array}$ & Eyes, ovaries, eggs \\
\hline & & Palaemonetes intermedius & $\mathrm{H}$ & Hepatopancreas & White chromatophores \\
\hline & & Penaeus duorarum & I & Hepatopancreas & External setae \\
\hline & & Pagurus maclaughlinae & $\mathrm{L}$ & & \\
\hline \multirow[t]{11}{*}{ MOLLUSCA } & Gastropoda & Bittium varium & $\mathrm{H}$ & Dorsal anterior soft tissue & \\
\hline & & Cerithium muscarum & $\mathrm{H}$ & Dorsal anterior soft tissue & Gills \\
\hline & & Astyris lunata & $\mathrm{H}$ & Dorsal anterior soft tissue & Gills, siphon \\
\hline & & Crepidula convexa & $\mathrm{H}$ & Anterior soft tissue & Ovaries, eggs \\
\hline & & Modulus modulus & $\mathrm{H}$ & Epibiota on shell & Gills \\
\hline & & Nassarius vibex & $\mathrm{H}$ & Dorsal anterior soft tissue & Gills \\
\hline & & Prunum apicinum & $\mathrm{H}$ & Dorsal anterior soft tissue & Gills, siphon \\
\hline & & Turbonilla incisa & $\mathrm{H}$ & Dorsal anterior soft tissue & Gills \\
\hline & & Haminoea antillarum & $\mathrm{H}$ & Dorsal anterior soft tissue & Gills \\
\hline & & Neritina virginea & $\mathrm{H}$ & Dorsal anterior soft tissue & Gills \\
\hline & & Melongena corona & $\mathrm{H}$ & Dorsal anterior soft tissue & Gills, siphon \\
\hline
\end{tabular}

epifauna were minor except in the case of the amphipod Cymadusa compta.

The survivorship of epifauna in the laboratory appeared little affected by treatment with stain. No significant differences in survivorship of the 4 species tested were found between stain-treatments and controls at Days 1 and 3. Although survivorship of 1 species, Palaemonetes intermedius, was slightly lower in stain-treatments at Day 7 (Table 2), overall the data suggest effects are negligible.

Results of in situ turnover experiments run over 3 and $6 \mathrm{~h}$ are shown in Fig. 2. Values for percent stained
Table 2. Mean numbers ( \pm SD) of surviving individuals in stain-treated and control replicates, at Day 7. At Day 0, replicates $(n=4)$ consisted of 20 individuals of each species. $\mathrm{ns}=$ not significantly different, $t$-test, $\mathrm{p}>0.05^{\circ}=$ significantly different, $0.05>\mathrm{p}>0.02$

\begin{tabular}{|lccc|}
\hline \multicolumn{1}{|c}{ Species } & \multicolumn{3}{c|}{ Number surviving } \\
& Stain & Control & \\
& & & \\
\hline Hippolyte pleuracanthus & $17.3 \pm 1.3$ & $13.3 \pm 4.3$ & $\mathrm{~ns}$ \\
Palaemonetes intermedius & $16.5 \pm 1.3$ & $18.8 \pm 1.0$ & $\cdot$ \\
Bittium varium & $20 \pm 0$ & $20 \pm 0$ & $\mathrm{~ns}$ \\
Astyris lunata & $20 \pm 0$ & $19.8 \pm 0.5$ & $\mathrm{~ns}$ \\
& & & \\
\hline
\end{tabular}

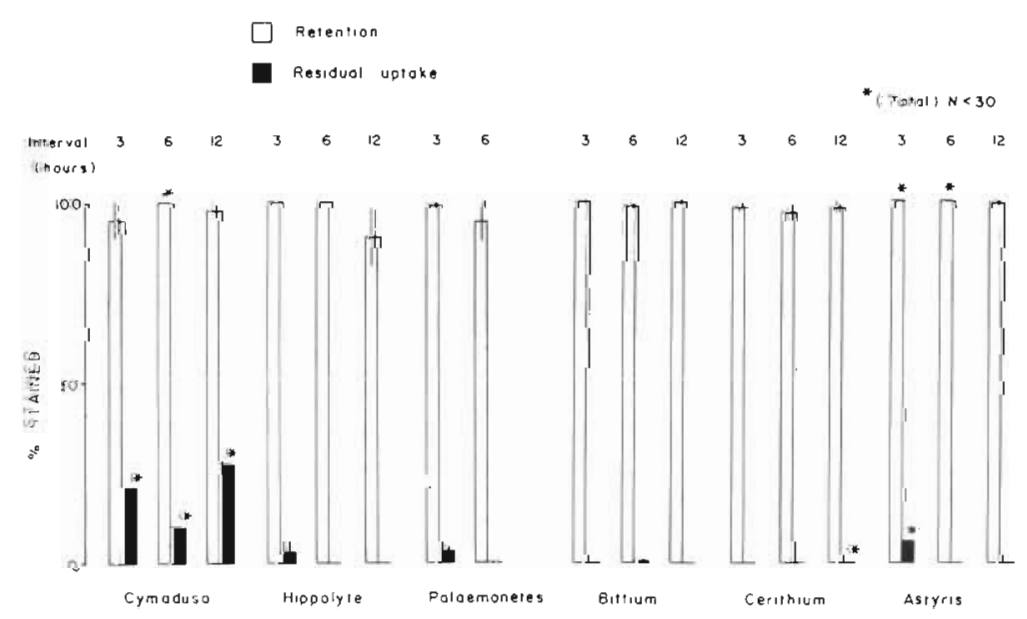

Fig. 1. Efficiency of stain retention by treated epifauna (open bars) and incidence of apparent staining of untreated epifauna exposed to residual stain (closed bars) in 3,6 and $12 \mathrm{~h}$ field tests. Only numerically dominant species of Table 1 are shown. Values are mean percent stained ( $\pm \mathrm{SE}$ ) of the total number of individuals. replicates pooled, number of individuals low $(<30)$. Insufficient numbers of Palaemonetes intermedius were obtained for the $12 \mathrm{~h}$ interval 


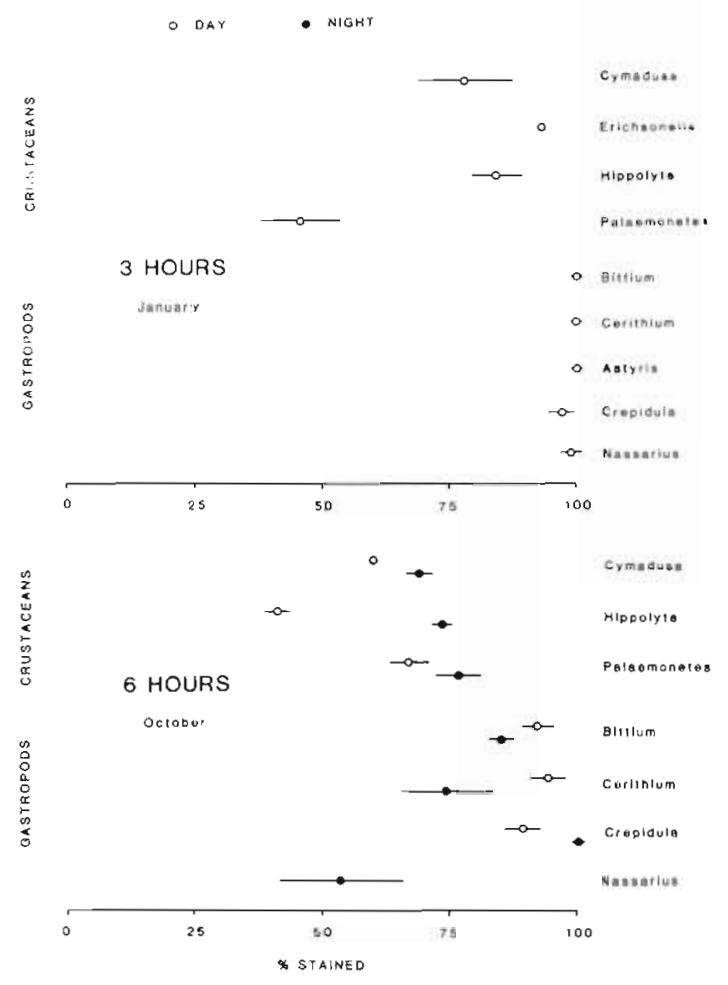

Fig. 2. Mean percent of recovered individuals stained ( $\pm \mathrm{SE}$ ) 3 and $6 \mathrm{~h}$ after in situ stain-treatment of $0.56 \mathrm{~m}^{2}$ replicate areas of seagrass substrate $(n=4)$. Replicates of $<10$ individuals of a species are excluded. Where error bars are not given, the total number of individuals is low $(<30)$, and replicates are pooled

after 3 h ranged from $<50 \%$ for the caridean shrimp Palaemonetes intermedius to $100 \%$ for the gastropod Astyris lunata. The turnover of all gastropod species was low relative to crustaceans, though values for the latter covered a wide range.

Most taxa showed a higher turnover of individuals in $6 \mathrm{~h}$ experiments (Fig. 2). An exception was Palaemonetes intermedius. In comparison with the diurnal $6 \mathrm{~h}$ experiment, significantly higher turnover of the gastropods Cerithium muscarum and Crepidula convexa occurred at night, while the inverse was true for Hippolyte pleuracanthus (Fig. 2). Values for other species did not differ significantly between day and night (ttest, $\mathrm{p}>0.05$ ).

\section{DISCUSSION}

In field tests, most epifaunal species associated with the seagrass Halodule wrightii were effectively marked in situ by exposure to 8 to $10 \mathrm{mg} \mathrm{l}^{-1}$ of neutral red. Although laboratory tests indicated staining of epifauna occurred at concentrations below $5 \mathrm{mg} \mathrm{l}^{-1}$, results were considerably less reliable both in terms of the intensity of staining and the proportion of individuals which could be unequivocally identified as stained.
High stain concentrations (> $10 \mathrm{mg} \mathrm{l}^{-1}$ ) were avoided in order to reduce the possibility of inducing behavioural artifacts in treated epifauna. The use of lower stain concentrations also should decrease the likelihood of uptake of residual stain by non-target animals moving into a previously stained area.

Results of field tests of stain retention by epifauna indicated that in situ staining provided an effective marker for periods of up to $12 \mathrm{~h}$. In the laboratory, stain could be retained by epifauna for several days. However, the intensity of stain and the proportion of individuals remaining recognizably stained decreased noticeably in $24 \mathrm{~h}$. Although retention times may be extended by the use of higher stain concentrations, the staining method, as specified here, is applicable only to more short-term studies. Where movements over a few hours are of primary interest, retention times are adequate.

Hence, for the majority of species, a high degree of confidence can be placed in the assumptions that (1) individuals present within boxes when treated with stain will remain marked for at least $12 \mathrm{~h}$, and (2) these epifauna can be distinguished from those that later move into the treated area. The ratio of unstained/ stained individuals will thus provide a measure of the temporal stability or 'turnover' of epifauna within defined areas.

Nevertheless, there are exceptions (Table 1, Fig. 1), requiring that all taxa need be tested for suitability prior to the application of the technique. The apparent uptake of residual stain by -10 to $25 \%$ of Cymadusa compta (Fig. 1) is anomalous. On closer examination of unstained $C$. compta it was discovered that the likely source of this result was a naturally occurring internal red pigmentation. In a check of untreated, field collected C. compta, 22 of 100 individuals were mistakenly judged as 'stained'. Red pigmentation appeared associated with female gonadal tissue. Hence, the proportions of unstained C. compta in turnover experiments (Fig. 2) probably are underestimated.

Although there was no effect of treatment with stain on survivorship of epifauna under laboratory conditions, less obvious treatment-induced artifacts have yet to be tested. Altered levels of activity of treated individuals, for example, for altered attractiveness of treated substrate to epifauna would bias results of field experiments. Differential predation on stained individuals also is conceivable. Nevertheless, the risk of producing such artifacts is kept to a minimum by (a) use of a very low stain concentration, i.e. $<1 \%$ of that used in previous applications of neutral red marking (Smith \& Present 1983), (b) rapid dispersal of stain from the water in and around the experimental area after treatment; (c) the short duration of field experiments.

In situ measurements of turnover indicated that dis- 
tributions of crustacean epifauna were highly dynamic. Gastropods appeared less mobile. Lower turnover of gastropods intuitively is related to their slower mode of locomotion. Nevertheless, as seen in the $6 \mathrm{~h}$ experiment, turnover of some gastropods may be comparable to that of crustaceans, suggesting that despite the potentially rapid mobility of most crustacean species, high levels of directional locomotory activity may be unusual or sporadic, e.g. peracaridean crustaceans may remain relatively sedentary as a result of domicolous (Cymadusa compta) or 'leaf-clinging' (Erichsonella attenuata) adaptations. Large carnivorous or omnivorous gastropods which actively search out prey, e.g. Nassarius vibex, are capable of sustaining relatively rapid crawling movement that may be reflected in observed high turnover rates (Fig. 2). Slower redistribution of Bittium varium and Cerithium muscarum in $6 \mathrm{~h}$ is perhaps linked to their herbivorous habits.

The relative mobilities of epifaunal groups as indicated by staining experiments appear to correlate well with relative rates of colonization observed in experiments carried out at the study site utilizing artificial seagrass. When clumps of artificial grass were set out for $1 \mathrm{~d}$ in a small sand patch adjacent to a seagrass bed, caridean and peracaridean crustaceans and the gastropod Nassarius vibex were the most abundant colonizing epifauna, relative to their 'background' abundances in surrounding seagrass (Virnstein \& Curran unpubl.).

These preliminary results suggest that crustacean taxa may show complete turnover of individuals in $0.56 \mathrm{~m}^{2}$ areas of substrate in less than $1 \mathrm{~d}$. Turnover of most gastropod species may occur over intervals of a few days.

Conclusions of recent colonization studies (Bell \& Devlin 1983, Virnstein \& Curran unpubl.), that epifauna can be extremely mobile, are supported.

Acknowledgements. I thank K. D. Cairns, M. A. Capone, P. S. Mikkelsen and R. W. Virnstein for their assistance during the study. R. W. Virnstein, F. G. Lewis and P. Jernakoff provided helpful suggestions during manuscript preparation. Harbor Branch Foundation Contribution No. 432

\section{LITERATURE CITED}

Alldredge, A. L., King, J. M. (1980). Effects of moonlight on the vertical migration patterns of demersal zooplankton. J. exp. mar. Biol. Ecol. 44: 133-156

Alldredge, A. L., King, J. M. (in press). The distance demersal zooplankton migrate above the benthos: implications for predation. Mar. Biol.

Bell, S. S., Devlin, D. J. (1983). Short-term macrofaunal recolonization of sediment and epibenthic habitats in Tampa Bay, Florida. Bull. mar. Sci. 33: 102-108

Dauer, D. M., Ewing, R. M., Tourtellottee, G. H., Barker, H. R., Jr. (1980). Nocturnal swimming of Scolecolepides viridis (Polychaeta: Spionidae). Estuaries 3: 148-159

Gore, R. H., Gallaher, E. E., Scotto, L. E., Wilson, K. A. (1981). Studies on decapod Crustacea from the Indian River region of Florida, XI. Community composition, structure, biomass, and species-areal relationships of seagrass and drift algae-associated macro-crustaceans. Estuar. coast. mar. Sci. 12: 485-508

Gunnill, F. C. (1982). Macroalgae as habitat patch islands for Scutellidium lamellipes (Copepoda: Harpacticoida) and Ampithoe tea (Amphipoda: Gammaridae). Mar. Biol. 69: 103-116

Hobson, E. S., Chess, J. R. (1979). Zooplankton that emerge from the lagoon floor at night at Kure and Midway Atolls, Hawail. Fish. Bull. U. S. 77: 275-280

Hoskin, C. M. (1983). Sediment in seagrasses near Link Port, Indian River, Florida. Fla Sci. 46: 153-161

Nixon, D. E. (1976). Dynamics of spatial pattern for the gas. trotrich Tetranchyroderma bunti in the surface sand of high energy beaches. Int. Revue ges. Hydrobiol. 61: 211-248

Ohlhorst, S. L. (1982). Diel migration patterns of demersal reef zooplankton. J. exp. mar. Biol. Ecol. 60: 1-15

Robertson, A. I., Howard, R. K. (1978). Diel trophic interactions between vertically-migrating zooplankton and their fish predators in an eelgrass community. Mar. Biol. 48: $207-213$

Sherman, K. M., Coull, B. C. (1980). The response of meiofauna to sediment disturbance. J. exp. mar. Biol. Ecol. 46: $59-71$

Smith, C. R., Present, T. M. C. (1983). In vivo marking of shallow-water and deep-sea amphipods by ingestion of bait mixed with fast green. Mar. Biol. 73: 183-192

Thistle, D. (1980). The response of a harpactacoid copepod community to a small-scale natural disturbance. J. mar. Res. 38: 381-395

Williams, A. B., Bynum, H. (1972). A ten year study of meroplankton in North Carolina estuaries. Chesapeake Sci. 13: 175-192 